\title{
Impacts of Characteristics of Economic Sectors and Industry Sectors on Business Efficiency of Vietnamese Enterprises by the analysis of variance
}

\author{
Pham Quang Tin, Pham Kim Ngoc, Nguyen Tran Thuan, Doan Gia Dung \\ Danang University of Economics, The University of Danang, Vietnam
}

\begin{abstract}
Since the Sixth National Congress of Vietnamese Communist Party (1986), Vietnam has implemented several policies and plans on improving Vietnam's economy by means of diversifying both economic sectors and industry sectors. There have been some experimental studies assessing the performance efficiency of these economic sectors and industry sectors (ESIS) at macro level. However, the research about impacts of ESIS characteristics on enterprise's efficiencyishardlyfound. Particularly, research into simultaneous impacts of both ESIS on enterprise's efficiency has been limited. Hence, this article utilizes the analysis of variance (ANOVA) to grasp the impacts of ESIS on enterprise's efficiency as a basis for implied policy proposals to related parties in promoting development of Vietnamese enterprises.
\end{abstract}

Keywords: Business efficiency; ROA; analysis of variance; economic sectors; industry sectors

\section{Introduction}

As part of communication process, advertisement delivers product information, stimulates the needs of consumers or induces consumer purchase behavior through advertisement massages. Advertisement motivates consumers to have linking and reliability toward products and services (Lee, Seong Gu, 1999). As such, advertisement seeks to deliver the contents and information to consumers effectively for the purpose of persuading them. The purpose of advertisement is to persuade the recipient and thereby maximize communication efficiency.

Based on characteristics of equity ownership, Vietnamese enterprises are classified into three major groups of economic sectors (ES): state-owned sector, non-state owned sector and foreign invested sector with the detailed component as below:

- State-owned sector (SOS): one-member limited liability companies with $100 \%$ of state-owned capital; joint-stock companies and limited liability companies with above 50\% of state-owned capital

- Non-state owned sector (NSOS): types of cooperatives and unions of cooperatives; limited liability companies with $\leqslant 50 \%$ of state-owned capital; joint stock companies with $\leqslant 50 \%$ of state-owned capital.

- Foreign invested sector (FIS): enterprises with $100 \%$ of foreign direct investment; private enterprises or state-owned enterprises joint venture with foreign partners.

In the Sixth National Congress of Vietnamese Communist Party (1986), Vietnam approved the diversification of ownership and multi-sector commodity economy. On December 29, 1987, Vietnam's Parliament officially passed the Law of Foreign Investment, approving the FIS in Vietnam. During the 
process of monitoring the nation, there have been changes in Vietnamese government's and Vietnamese Communist party's policies, allowing the multi-sector economy and facilitating the improvement of different ES, nonetheless still maintaining the development of state-owned economy sector which plays the primary role in the economy. Thus, Vietnam government has incentives to orientate the development of state-owned economy sector as compared with others.

Based on business lines, Vietnamese enterprises are divided into three major groups of industry sector, according to International Stander Industrial Classification of all Economic Activities (ISIC), as well as the rules of economic classification of Vietnamese government (Decision 10 of Prime Minister in year of 2007-10/2007/QĐ-TT) including: Agriculture, Forestry and Fishing sector (AFFS), Manufacturing sector (MS) and Service sector (SS). Determined to make SOS the primary economic sector in Vietnam, the Seventh National Congress of Vietnamese Communist Party in the year of 1991; the Eighth National Congress in 1996 and the Eleventh National Congress in 2011 have specified strategies for building Vietnam's economy in the direction of industrialization, prioritizing the orientation of developing manufacturing and service groups in preference to agriculture, forestry and fishing.

The fact that Vietnam has various incentives and policies in monitoring resources for the growth of state-owned economic sectors, manufacturing and service sector has affected all business activities. In fact, there have been some experimental studies assessing the business performance of different economic sectors and industry sectors in Vietnam as below:

- About the investment efficiency of different economic sectors: according to the research findings of Nguyen Tran Que (2004), Nguyen Thuy Huong (2009), Pham Minh Chinh Vuong Quan Hoang (2009), Hoang Sy Dong (2014); the investment efficiency of different economic sectors in Vietnam was not the same

- About the investment efficiency of different industry sectors: according to the research findings of Nguyen Thi Canh (2012), Nguyen Thi Thanh Tuyen (2012), Doan Lien Diem (2012), Bui Quang Binh (2010); the investment efficiency of different industry sectors in Vietnam was not the same

Although there have been many experimental studies into the business performance of economic sectors and industry sectors by the investment efficiency ratio, the rigorous studies into how enterprise's detail business performance affected by economic sector or industry sector in Vietnam, especially affected by both criteria of economic sectors and industry sectors have not been studied. For this reason, this article used quantitative approaches to study impacts of characteristics of economic sectors and industry sectors on enterprises' business efficiency to form the basis for suggestions of better development of Vietnamese enterprises indifferent economic sectors and industry sectors. The rest of this study is organized as follows: section 2 provides related literature; section 3 presents research design; section 4 shows the research findings and section 5 concludes the study.

\section{Literature review and research questions}

To analyze the impacts of economic sectors and industry sectors on enterprises' business efficiency in Vietnam, the authors mainly investigate the theory of comparative advantage of David Ricardo (1817). According to David Ricardo, enterprises with different characteristics in equity ownership would have different advantages, which results in the difference in business efficiency. In other words, enterprises in different economic sectors should have their own competitive advantages that will contribute to different business performance. 
According to Hymer's research in the United States (1976), foreign invested enterprises enjoy the benefits of capital, technology and management skills. Meanwhile, domestic enterprises have advantages of tradition and understanding of consumption market. As a result, foreign invested enterprises and domestic enterprises will tend to have different business efficiency.

The research of Loree - Guisinger (1995) mentioned "The Government's advantage of the investment incentives". Loree - Guisinger asserted that there have been various preferences of governmental investment to different ESin different countries; as a result, investment efficiency among economic sectors varies. This means that enterprises of SOS, NSOS and FIS have dissimilar preferences of investment causing the divergence in business performance.

In order to assess impacts of economic sectors on business performance of enterprise, it is necessary to answer question (01): "Do Vietnamese enterprises of different economic sectors perform differently?"

In addition to the impact of economic sectors, enterprises from different industry sectors in the same economic sector will have advantages which cause the variance in business efficiency. Based on the National Economic Classification according to System of National Accounts (SNA) of United Nations (1989) and the System of Vietnam's National Economic Classification by the decision number: 10/2007/QĐ-TTg, all economic activities are classified into 21 primary groups pertaining to 3 main industry sectors: Agriculture, Forestry, Fishing; Manufacturing and Service. The business process of each industry sector would have different requirements and features; implying enterprises from different industry sectors would have different advantages leading to the variation in their performance.

In order to assess impacts of industry sectors on business efficiency of enterprise, it is necessary to answer question (02):"Do Vietnamese enterprises of different industry sectors perform differently?"

The research questions (01) and (02) can explain the separate impacts of economic sector characteristics and industry sector characteristics on enterprises' business efficiency but fail to explain the simultaneous impacts of ESIS on it. LilachNachum(2004)studying 345 companies at developing countries showed the impacts of different business areas and ownership structures on business efficiency. SomnathLahiri and SaptarshiPurkayastha(2015) after studying Indian companies in the period 2004-2008 showed business efficiency was affected by their business lines and economics sectors. Besides, there are experimental studies of authors: Kwangmin Park -Soo Cheong (Shawn) Jang (2012) and ChiungJung Chen - Chwo Ming Joseph Yu (2012) supporting the mentioned opinion. With the aim of explaining the simultaneous impacts of ESIS on Vietnamese enterprises' efficiency, it is essential to answer (03): "Do Vietnamese enterprises of different economic sectors or different industry sectors perform differently?"

In other words, does this means Vietnamese enterprises of different economic sectors but similar industry sectors, or similar economic sectors but different industry sectors, or enterprises of difference in both perform differently?

Enterprise's business efficiency is compared between its outputs and inputs. In this research, enterprise's business efficiency is measured with Return On Assets (ROA). ROA is one of the ratios reflecting business efficiency where the higher value indicates the higher business efficiency. Therefore, impacts of characteristics of EST on enterprise's ROA can be referred to as impacts on their business efficiency. 


\section{Research design}

\subsection{Analysis methods}

The research uses variance of analysis (ANOVA) to analyze the data. ANOVA is a statistical analysis technique used to examine if the null hypothesis of population means are equal (at least 3 populations) by means of sample data and the purpose of examining effects of reasons and results.

Conditions of reliable results of ANOVA according to Anderson (2014):

- For each population, the response variable is normally distribution.

- The variance of the dependent variable (result variance) must be equal.

\subsubsection{One-way ANOVA}

One-way ANOVA is a technique examining impacts of anindependent variable (qualitative variable) on a dependent variable (quantitative variable). Results of one-way ANOVA are to conclude the population means are equal (01):

$\mathrm{H}_{0.1}$ : Population means are equal.

$\mathrm{H}_{1.1}$ : Population means are not equal.

Population of hypotheses (01) is specified based on characteristics of anindependent variable (a qualitative variable). In order to fit one-way ANOVA,the independent variable (qualitative variable) has to have at least three separate characteristics to form 3 different research populations. Results of one-way ANOVA are illustrated in table (01):

Table 01: Results of One-way ANOVA in a general format:

\begin{tabular}{|l|l|l|l|l|}
\hline $\begin{array}{c}\text { Source of } \\
\text { Variation }\end{array}$ & $\begin{array}{c}\text { Sum of } \\
\text { squares }\end{array}$ & $\begin{array}{c}\text { Degree of } \\
\text { Freedom }\end{array}$ & Mean squares & F ratio \\
\hline Between-groups & SSG & $\mathrm{k}-1$ & MSG=SSG/(k-1) & F=MSG/MSW \\
\hline With-groups & SSW & $\mathrm{n}-\mathrm{k}$ & MSW=SSW/(n-k) & \\
\hline Total & SST & $\mathrm{n}-1$ & & \\
\hline
\end{tabular}

SSG: Sum of squares between groups; K: number of groups; SSW: Sum of squares within groups, n: observed sample; SST: total sum of squares.

Comparing the value of $\mathrm{F}$ ratio with the $\mathrm{F}$ value of standard normal distribution table to make a foundation for disproving or not disproving the equivalence of population means of general hypothesis (01)

In order to assess impacts of characteristics of economic sectors on business efficiency of Vietnamese enterprises with one-way ANOVA, research question (01) should be replaced with a research hypothesis (02):

$\mathrm{H}_{0.2}:$ ROA of enterprises whose characteristics of economic sectors are different are equal.

$\mathrm{H}_{1.2}$ : ROA of enterprises whose characteristics of economic sectors are different are not equal.

The independent variable (qualitative variable) in hypothesis (02) is characteristics of economic sectors of enterprises. In Vietnam, based on the classification of economic sectors, all enterprises classify into 3 groups (3 populations): SOS, NSOS and FIS, whichmatchone-way ANOVA. Likewise, in order to assess impacts of characteristics of industry sectors on enterprises' business efficiency with one-way ANOVA, research question (02) should be replaced with a hypothesis (03) studying: 
$H_{0.3}: R O A$ of enterprises whose characteristics of industry sectors are different are equal.

$H_{1.3}:$ ROA of enterprises whose characteristics of industry sectorsare different are not equal.

The independent variable (qualitative variable) in the hypothesis (03) is characteristics of business lines of enterprises. In Vietnam, based on the classification of business sectors, all enterprises classify into 3 groups (3 populations): Agriculture, Forestry, Fishing; Manufacturing and Service Industry, which matches one-way ANOVA.

\subsubsection{Two-way ANOVA}

One-way ANOVA can only answer research questions (01) and (02), in order to answer research question (03), it is necessary to utilize two-way ANOVA. Two-way ANOVA is a technique examining impacts of two independent variables (qualitative variables) on a dependent variable (quantitative variable). Results of two-way ANOVA are to conclude the populations' means are equal of general hypotheses (04):

$H_{0.4}$ : Population means are equal.

$H_{1.4}$ : Population means are not equal

Populations of the hypothesis (04) are specified based on characteristics of two independent variables (qualitative variables). The first independent variable (qualitative variable) has $\mathrm{K}$ feature (K groups) and the second one has B features (B groups), which form K.B different research populations. Results of two-way ANOVA are illustrated in table (02):

Table 02: Results of two-way ANOVA in a general format

\begin{tabular}{|l|l|l|l|l|}
\hline $\begin{array}{c}\text { Source of } \\
\text { Variation }\end{array}$ & $\begin{array}{c}\text { Sum of } \\
\text { squares }\end{array}$ & $\begin{array}{c}\text { Degree of } \\
\text { Freedom }\end{array}$ & Mean squares & F ratio \\
\hline Between-groups & SSG & K-1 & MSG=SSG/(K-1) & F1=MSG/MSE \\
\hline Between-blocks & SSB & B-1 & MSB=SSB/(B-1) & F2=MSB/MSE \\
\hline Interaction & SSI & $(\mathrm{K}-1)(\mathrm{B}-1)$ & MSI=SSI/(K-1)(B-1) & F3=MSI/MSE \\
\hline Error & SSE & n-(BK-1) & MSE=SSW/(n-(KB-1)) & \\
\hline Total & SST & N & & \\
\hline
\end{tabular}

SSG: Sum of squares between groups formed from K groups;SSB: Sum of squares between groups formed from K groups. SSI: Sum of squares interactionformed from K.B groups; SSE: Sum of squares error; SST: Sum of squares total, $n$ : observed sample

Comparing the value of $\mathrm{F} 3$ ratio with the $\mathrm{F}$ value of standard normal distribution table to make a foundation for disproving or not disproving the equivalence of population means of hypothesis (04) In order to assess simultaneous impacts of EST on enterprises' business efficiency with two-way ANOVA, research question (03) should be replaced with a research hypothesis (05):

$H_{0.5}$ : ROA of enterprises whose characteristics of economic sectors or industry sectors are different are equal.

$H_{1.5}: R O A$ of enterprises whose characteristics of economic sectors or industry sectorsare different are not equal.

Population of the hypothesis (05) is specified based on the combination of economic sectors ( 3 groups) and industry sectors (3 groups), which forms the sum of 9 research populations. 


\subsection{Research data}

Data resources of this research based mainly on data of enterprise-investigating 2015 of four regions: Hue, DaNang, QuangNam and QuangNgai, all of which are included in the enterprise-investigating program held by The General Statistics Office Vietnam (GSO) in the year 2015.

According to the result of investigation program in Hue, Da Nang, Quang Nam and QuangNgai in 2015, there have been some startup companies since 2014, which lead to the lack of information for involving ratios. Thus, enterprises without full data will be eliminated to guarantee the representativeness of estimates and testing conducted in the research.

Table 03: Distribution of sample research enterprises of economic sectors and industry sectors

\begin{tabular}{|l|l|l|l|l|}
\hline \multirow{2}{*}{ Industry sectors } & \multicolumn{2}{|l|}{ Economic sectors } & \multirow{2}{*}{ Total } \\
\cline { 2 - 5 } & $\begin{array}{l}\text { State- } \\
\text { owned } \\
\text { sector }\end{array}$ & $\begin{array}{l}\text { Non-state } \\
\text { owned sector }\end{array}$ & $\begin{array}{l}\text { Foreign } \\
\text { invested sector }\end{array}$ & 580 \\
\hline $\begin{array}{l}\text { Agriculture, forestry and } \\
\text { fishing }\end{array}$ & 222 & 301 & 57 & 2,137 \\
\hline Manufacturing & 253 & 1,602 & 282 & 2,016 \\
\hline Service & 133 & 1,565 & 318 & 4,733 \\
\hline Total & 608 & 3,468 & 657 & \\
\hline
\end{tabular}

The total number of enterprises surveyed in the research is 4,733 enterprises distributed as data shown in table 03. Results of survey sample distribution inherit from the structure of enterprise survey samples by the GSO in Vietnam, apportioned based on the proportion of Vietnamese enterprises of economic sectors and industry sectors, therefore data of survey samples ensures the representativeness of estimates and testing in this research.

\section{Research findings}

The research data have been tested the variance equivalence of the populationsbased on the Homogeneity testing standards and eachanalyzed group always hasmore than 30 observations (Data shown in table 03) thus average values follow the standard distribution, meeting the requirement of ANOVA. To decrease complicated calculating work, this article uses results drawn from statistical analysis software in an attempt to form a basis for assertions of testing results and statistical estimates.

\subsection{Impacts of characteristics of economic sectors on enterprises' business efficiency.}

Table 04: ROA estimated results of enterprises of different economic sectors

\begin{tabular}{|c|c|c|c|c|}
\hline \multirow{2}{*}{ Types of enterprises } & \multirow{2}{*}{$\mathbf{N}$} & \multirow{2}{*}{$\begin{array}{l}\text { Mean } \\
(\%)\end{array}$} & \multicolumn{2}{|c|}{ 95\% Confidence Interval for Mean (\%) } \\
\hline & & & Lower Bound & Upper Bound \\
\hline State owned & 608 & -0.23 & -1.58 & 1.11 \\
\hline
\end{tabular}




\begin{tabular}{|c|c|c|c|c|}
\hline Non-state owned & 8 & 3.35 & 2.95 & 3.75 \\
\hline Foreign invested & 657 & 1.53 & 0.13 & 2.94 \\
\hline Total & $3^{473}$ & 2.64 & 2.24 & 3.03 \\
\hline
\end{tabular}

ROA estimated results of Vietnamese enterprises by point estimatebeing $2.64 \%$ with confidence interval of $95 \%$ by interval estimate from $2.24-3.03 \%$. In which, ROA of enterprises inthe non-state owned economic sectors is the highest with the point estimate being $3.35 \%$ and the interval estimate between $2.95-3.75 \%$. ROA value of enterprises of foreign invested economic sectors comes second with $1.53 \%$ and interval estimate between $0.13-2.94 \%$. What should be noticed is that enterprises of state-owned economic sectors has very low average ROA value of $-0.23 \%$ which shows that their business performance is far less efficient than those other types of economic sectors. Mean while, Vietnamese government's orientation is to develop SOS as main role in the economy, which is unsuitable for the rule of value.

Table 05: Results of ANOVA about impacts of characteristics of ES on ROA

\begin{tabular}{|c|c|c|c|c|c|}
\hline & Sum of Squares & Df & \begin{tabular}{|} 
Mean \\
Square
\end{tabular} & $\mathbf{F}$ & Sig \\
\hline Between Groups & $7,566.510$ & 2 & $5^{3,783.25}$ & 20.080 & .000 \\
\hline Within Groups & $891,194.645$ & 4,730 & 188.413 & & \\
\hline Totals & $898,761.155$ & 4,732 & & & \\
\hline
\end{tabular}

Data in table 05 has sig $=0.000<5 \%$ (The probability of making errors when disproving null hypothesis) therefore the research has the foundation of disproving the null hypothesis $\mathrm{H}_{0.2}$. In other words, with the significant level of $5 \%$, it is possible to conclude that "characteristics of EShave an impact on enterprises' ROA". This means that in the condition factors affecting enterprises' business efficiency are alike but business efficiency of enterprises whose characteristics of economic sectors are different is unequal.

Table 06: Results of ROA estimated deviation of economic sectors

\begin{tabular}{|c|c|c|c|c|}
\hline \multirow{2}{*}{$\begin{array}{c}\text { (I) Types } \\
\text { of enterprises }\end{array}$} & \multirow{2}{*}{$\begin{array}{l}\text { (J) Types of } \\
\text { enterprises }\end{array}$} & \multirow{2}{*}{$\begin{array}{c}\text { Mean } \\
\text { Difference } \\
(\mathrm{I}-\mathrm{J})(\%)\end{array}$} & \multicolumn{2}{|c|}{$\begin{array}{l}\text { 95\% Confidence Interval } \\
(\%)\end{array}$} \\
\hline & & & Lower Bound & $\begin{array}{l}\text { Upper } \\
\text { Bound }\end{array}$ \\
\hline $\begin{array}{l}\text { Non-state } \\
\text { owned }\end{array}$ & State-owned & 3.58 & 2.17 & 5.00 \\
\hline $\begin{array}{l}\text { Non-state } \\
\text { owned }\end{array}$ & Foreign invested & 1.82 & 0.45 & 3.18 \\
\hline $\begin{array}{l}\text { Foreign } \\
\text { invested }\end{array}$ & State owned & 1.77 & 0.04 & 3.58 \\
\hline
\end{tabular}


There is a huge difference between the average values of ROA of enterprises in different economic sectors. Inpoint estimate,non-state owned enterprises are 3.58\% higher than state owned ones and $1.82 \%$ higher than those with foreign investment. Based on interval estimate with confidence level being $95 \%$, average ROA of non-state owned enterprises is 2.17 - equivalent to $5 \%$ higher than state owned ones and 0.45 - approximately $3.18 \%$ higher than those with foreign investment. ROA of enterprises with foreign investment is higher than state-owned enterprises by point estimate being $1.77 \%$ and by interval estimate being 0.04 - about $3.58 \%$.

Ignoring other elements and simply considering enterprise's efficiency of business activities based on ROA, Vietnam should orientate priority for development: Non-state owned enterprises, enterprises with foreign investment respectively. State-owned enterprises should not be prioritized to invest budget in, resources should be poured on efficient types of other economic sectors.

\subsection{Testing impacts of characteristics of industry sector on enterprises' business efficiency}

Table 07: ROA Estimated results of enterprises of different industry sectors

\begin{tabular}{|c|c|c|c|c|}
\hline \multirow{2}{*}{ Industry sector } & \multirow{2}{*}{$\mathbf{N}$} & \multirow{2}{*}{$\begin{array}{l}\text { Mean } \\
(\%)\end{array}$} & \multicolumn{2}{|c|}{ 95\% Confidence Interval for Mean (\%) } \\
\hline & & & Lower Bound & Upper Bound \\
\hline $\begin{array}{l}\text { Agriculture, Forestry and } \\
\text { Fishing }\end{array}$ & 580 & 2.77 & 1.73 & 3.80 \\
\hline Manufacturing & 2137 & 2.59 & 2.03 & 3.16 \\
\hline Service & 2016 & 2.65 & 2.01 & 3.28 \\
\hline Total & 4733 & 2.64 & 2.24 & 3.03 \\
\hline
\end{tabular}

Considering enterprise's industry sector, there is not so high deviation of ROA value among enterprises of different industry sectors. According to point estimate, the average value of ROA of enterprises in the field Agriculture and Forestry - Fishery is highest at $2.77 \%$, followed by Service Industry at $2.65 \%$ and the lowest value of ROA belonged to Manufacturing Sector at $2.59 \%$.

Besides, results of ANOVA in table 08 show the value of $\mathrm{Sig}=0.964>5 \%$ thus have no ground of disproving the null hypothesis $\mathrm{H} 0.3$ of hypothesis (03). In other words, with the significant level of 5\% it is possible to conclude: "ROA of enterprises whose characteristics of industry sectors are different is equal". This reflects that in Vietnam, characteristics of industry sectors do not have much of an impact on enterprise's business efficiency.

Table 08: Results of ANOVA of impacts of industry sector on ROA

\begin{tabular}{|l|l|l|l|l|l|}
\hline & Sum of Squares & Df & Mean Square & F & Sig. \\
\hline Between Groups & 13.744 & 2 & 6.872 & .036 & .964 \\
\hline Within Groups & 898747.411 & 4730 & 190.010 & & \\
\hline Total & 898761.155 & 4732 & & & \\
\hline
\end{tabular}




\subsection{Testing impacts of ESIS on enterprise's business efficiency}

Results of One-way ANOVA in table 05 and table 08 only allow research on separate impacts of economic sector or industry sector on enterprises' business efficiency but fail to reflect the simultaneous impacts of characteristics of their ESIS on their business efficiency.

Values of sig in table 09 are all smaller than 5\%. Therefore disproving the null hypothesis H0.5 means approving H1.5of the hypothesis (05): "ROA of enterprises whichESIS are different is unequal". This means enterprises whose ESIS are different would as a result have different business efficiency.

Table 09: Results of ANOVA of impacts of ESIS on ROA

\begin{tabular}{|l|l|l|l|l|l|}
\hline Source & Sum of Squares & Df & Mean Square & F & Sig. \\
\hline Economic sector & $7,062.227$ & 2 & $3,531.113$ & 18.834 & .000 \\
\hline Industry sector & $2,602.990$ & 2 & $1,301.495$ & 6.942 & .001 \\
\hline $\begin{array}{l}\text { Economic sectorx } \\
\text { Industry sector }\end{array}$ & $4,842.172$ & 4 & $1,210.543$ & 6.457 & .000 \\
\hline Errors & $885,669.885$ & 4,724 & 187.483 & & \\
\hline Total & $931,672.510$ & 4,733 & & & \\
\hline
\end{tabular}

Detailed research into ROA of enterprises according to ESIS shown in table 10 illustrates that:

For Agriculture, Forestry and Fishery: enterprises with foreign investment have the highest ROA at $3.98 \%$; followed by state-owned enterprises at $2.67 \%$ and non-state owned enterprises have the lowest at $2.61 \%$. This is a worrying concern to Vietnam, since its economy is traditionally agricultural though business effectiveness of state-owned enterprises is not as high as those with foreign investment. The reason for this is that Vietnamese enterprises of Agriculture and Forestry - Fishery industry have not prioritized the application of technology in Agriculture - Fishery, thus that fields have not created as high value added products. Enterprises with foreign investmentwith advantages of experience and technology have created high value added products. Especially, with production in a large scale, the efficiency of foreign invested enterprises becomes higher than enterprises of other sectors.

For Manufacture and Service Industry: non-state owned enterprises are having the highest ROA at $3.26 \%$ and $3.58 \%$, respectively higher than general average value at $2.59 \%$ and $2.65 \%$.In the meantime, the business efficiency of state-owned enterprises is extremely low and remains at a loss. Characteristics of Vietnamese non-state owned enterprises are small scale and low business capital, which suits the flexibility of Service Industry thus puts their ROA above other industry. ROA value of state-owned enterprises in Service Industry is worrying as it is $-4.99 \%$, which makes it obvious that those enterprises' performance in that field is inefficient and incompetent compared with other sectors. Therefore, state-owned enterprises should not be orientated to get promoted in such industry. Besides, in manufacture industry, theaverage value of ROA of the aforementioned enterprises is dramatically low at $-0.28 \%$, in comparison with the non-state owned enterprises at $3.58 \%$ and those with foreign investment at $1.39 \%$. Hence, state-owned enterprises should also not involve in manufactureindustry unless any breakthrough improvement is made so they could compete with their counterparts in other economic sectors. 
Table 10: ROA Estimated results of enterprises of ESIS (\%)

\begin{tabular}{|l|l|l|l|l|}
\hline \multirow{2}{*}{ Industry sector } & \multicolumn{2}{|l|}{ Economic sectors } & \multirow{2}{*}{ Total } \\
\cline { 2 - 5 } & State & Non-state & FDI & \\
\hline Agriculture, forestry and fishing & 2.67 & 2.61 & 3.98 & 2.77 \\
\hline Manufacturing & -0.28 & 3.26 & 1.39 & 2.59 \\
\hline Service & -4.99 & 3.58 & 1.22 & 2.65 \\
\hline Total & -0.23 & 3.35 & 1.53 & 2.64 \\
\hline
\end{tabular}

\section{Conclusion}

As can be viewed from research results, if the Vietnamese enterprises' business efficiency is based on ROA ratio, non-state owned enterprises for the highest, enterprises with foreign investment for the runner-up and the most worrying - state owned enterprises are in dire financial straits as their ROA has been below 0 . By simply considering the difference in industry sector, there is not a huge difference in business efficiency among these enterprises, or in other words, industry sector do not bring about advantages of making such a great difference.

Combining the two characteristics of economic sectors and industry sectors, it can be clearly seen that Vietnamese enterprises' performance differs greatly. In other words, their business effectiveness is under the influence of characteristics of both economic sectors and industry sector at the same time.

If we direct the enterprise development based on business efficiency, the rule of value says:

- State-owned enterprises should invest in Agriculture, Forestry and Fishing on the ground that their performance in this industry is better than in other fields namely Service and Manufacturing.

- Non-state owned enterprises should invest in Service industry and Manufacturing since their performance in these fields is better than in Agriculture, Forestry and Fishing.

- Enterprises with foreign investment has the highest business efficiency in Agriculture Forestry and Fishing at present, but their performance on Manufacturing and Service industry has not come up to expectations triggered by their potentials. Vietnam should take into account certain fields of Service industry and Manufacturing industry to attract investment of foreign enterprises. Additionally, it is necessary to investigate methods of accounting bookkeeping in these enterprises so as to accurately yield business performance to avoid "fake loss but real profit" as well as tax evasion.

This article has utilized the ANOVA, in particular Two-way ANOVA which is a statistical approach generating accurate research results in terms of quantifying the influence of ESIS on enterprises' business efficiency. However, the research team could only approach resources of survey data of 4 regions: Hue, Da Nang, Quang Nam and QuangNgai, which leads to the limit in generalization of the whole Vietnamese enterprises. In the future, our team will broaden the survey data of sample enterprises to all provinces and cities under the central, in an attempt to boost the reliability of estimated results and testing.

\section{References}

1. Bùi Quang Bình (2010), Mô hình tăng trưởng Kinh tế Việt Nam nhìn từ góc độ chuyển dịch cơ cấu, Kỷ yếu hội thảo khoa học: "Mô hình tăng trưởng kinh tế của Việt Nam: Thực trạng và lựa chọn cho giai đoạn 20112020. Nhà Xuất bản Đại học Kinh tế quốc dân, Hà Nội. (Tr 340 - 345). 
2. Nguyễn Thị Cành. (2012). Tình hình phát triển kinh tế nội ngành và chuyển dịch cơ cấu kinh tế Việt Nam trong giai đoạn đổi mới và hội nhập, Sánh Chuyển dịch cơ cấu kinh tế. Mô hình tăng trưởng kinh tế thành phố Hồ Chí Minh và Việt Nam theo hướng cạnh tranh đến năm 2020, NXB Tổng Hợp TPHCM, (Tr 48-65).

3. Phạm Minh Chính, Vương Quân Hoàng. (2009). Kinh tế Việt Nam: Thăng trầm và đột phá. Nxb Chính trị Quốc gia, Hà Nội.

4. Đoàn Liên Diễm. (2012). Tái cấu trúc nền kinh tế Việt Nam tiến đến phát triển bền vững, Sánh Chuyển dịch cơ cấu kinh tế. Mô hình tăng trưởng kinh tế thành phố Hồ Chí Minh và Việt Nam theo hướng cạnh tranh đến năm 2020, NXB Tổng Hợp TPHCM, (Tr 78-85).

5. Hoàng Sỹ Động. (2014). Tái cấu trúc kinh tế, đổi mới mô hình tăng trưởng trên cơ sở khai thác, phát huy tiềm năng, lợi thế, Tạp chí Nghiến cứu kinh tế, số 435 (08/2014), Trang (22-31).

6. Nguyễn Trần Quế. (2004). Chuyển dịch cơ cấu kinh tế Việt Nam trong những năm đầu thế kỷ 21. Nhà xuất bản Khoa học xã hội Hà Nội.

7. Nguyễn Thúy Hương (2009); Đầu tư trực tiếp nước ngoài năm 2008; Tạp chí Cộng Sản; số 759 (01/2009); Trang 49-56.

8. Nguyễn Thanh Tuyền. (2012). Suy giảm kinh tế 2008-2011: Một tác nhân tích cực thúc đẩy Việt Nam tái cơ cấu nền kinh tế theo hướng hội nhập, Sánh Chuyển dịch cơ cấu kinh tế, Mô hình tăng trưởng kinh tế thành phố Hồ Chí Minh và Việt Nam theo hướng cạnh tranh đến năm 2020, NXB Tổng Hợp TPHCM, (Tr 66-77).

9. Tổng cục Thống kê Việt Nam (2015); Quyết định: 13/QĐ-TCTK: "Về việc tổ chức điều tra doanh nghiệp năm 2015".

10. Thủ tướng chính phủ (2007); Quyết định số: 10/2007/QĐ-TTg "Hệ thống ngành kinh tế Việt Nam"; Hà Nội.

11. Anderson (2014); Statictics for Business and Economics 12e; South-Wstern.

12. Hymer S. H. (1976); The International operations of national firms: a study of direct foreign investment; Cambridge: MIT Press.

13. Loree D.W - Guisinger S.E. (1995), Policy and non-policy determinants of US equity foreign direct investment, Journal of International Business Studies, No 26, PP (281 - 299).

14. UN (1989); System of National Accounts.

15. Lilach Nachum (2004), Geographic and Industrial Diversification of Developing Country Firms, Journal of Management Studies, No (0022-2380).

16. Somnath Lahiri - Saptarshi Purkayastha (2015), Impact of industry sector on corporate diversification and firm performance: Evidence from Indian business groups, Canadian Journal of Administrative Sciences Revue canadienne des sciences de l'administration, Published online in Wiley Online Library (wileyonlinelibrary.com).

17. Chiung Jung Chen - Chwo Ming Joseph Yu (2012), Managerial ownership, diversification, and firm performance: Evidence from an emerging market, International Business Review, No (21), PP (518-534).

18. Kwangmin Park - Soo Cheong (Shawn) Jang (2012), Effect of diversification on firm performance: Application of the entropy measure, International Journal of Hospitality Management, No (31), PP (218-228). 